Proceedings of the $9^{\text {th }}$ International Scientific Conference Rural Development 2019

\title{
COMPARISON OF COSTS IN PRE-COMMERCIAL THINNING USING MEDIUM-SIZED AND SMALL-SIZED HARVESTERS
}

Santa KALĒJA, Latvian State Forest Research Institute "Silava”, Riga street 111, Salaspils, Latvia; santa.kaleja@silava.lv (corresponding author)

Agris ZIMELIS, Latvian State Forest Research Institute “Silava”, Riga street 111, Salaspils, Latvia; agris.zimelis@silava.lv

The aim of this study is to compare productivity and costs of medium-sized and small-sized harvesters in pre-commercial thinning. In this study the data on harvesting productivity were obtained in stands, where biofuel was prepared using two medium-sized and two small-sized harvesters equipped with different harvester heads. In total $677 \mathrm{~m}^{3}$ of wood was prepared with medium-sized harvester, but with small-sized harvesters $1164 \mathrm{~m}^{3}$ of wood was prepared. Although the total annual costs of small-class harvesters are lower by $16 \%$, comparing with middle-class harvesters, the productivity rates shown by the middle-class harvester John Deere 1070 E (equipped with H 754 harvester head) are significantly higher and the average wood preparation costs are lower, comparing with the other harvesters employed.

Keywords: medium-sized harvesters, small-sized harvesters, productivity, thinning

\section{INTRODUCTION}

According to the sustainable development strategy of Latvia until 2030, in $202040 \%$ of the final energy consumption should be provided by the renewables (Atjaunojamie..., 2010; Latvijas..., 2014). Small-dimension wood is the main biofuel resource to be obtained in pre-commercial thinning (Iwarsson Wide, 2008) and can significantly increase the use of local renewable resources (Lazdāns, 2008; Lazdiňš, 2014; Lazdiṇš, 2015). As the previous studies show, that amount of unused small-dimension wood is significant and in pre-commercial thinning constitutes from 700 to 900 thousand $\mathrm{m}^{3}$ annually (Lazdāns, 2006). The largest potential of energy wood in Latvia is concentrated in forest stands, whose age ranges from 21 to 30 years (the average tree height of the stand ranges from 10 to $11 \mathrm{~m}$ ) (Lazdāns, 2006; Lazdiņ̌s,

Copyright (C) 2019 The Authors. Published by Vytautas Magnus University. This is an open-access article distributed under the terms of the Creative Commons Attribution License (CC BY 4.0), which permits unrestricted use, distribution, and reproduction in any medium, provided the original author and source are credited. 
2013). Several different technical and technological solutions are possible regarding extraction of energy wood (Lazdiňs, 2012). Nowadays the energy wood and logs prepared in thinnings are delivered to industrial manufacture, which is related to certain quality standards, therefore also in Latvia, following the example of other Nordic countries, in the recent years pre-commercial thinnings are increasingly mechanized, however this process is slow and to a great extent influenced by the lack of qualified labour force and the large investments. Nowadays harvesters are built and classified according to their tasks and the suitability of the machine type for a certain felling type is mainly determined by machine dimensions, its ability to move in the felling site and its engine power. In Latvia medium-sized harvesters are mainly used in logging, because the machines are relatively compact and can be adapted to both thinnings and final fellings. In other Nordic countries in mechanized pre-commercial thinnings, where mostly energy wood is obtained, small and medium-sized harvesters, which are intended for processing of individual trees or whose felling heads are additionally equipped with the mechanism of accumulating several stems, are most frequently used (Kärhä, 2004). As there are no technical obstacles for preparation and processing of small-dimension wood, the main problem is economic efficiency (Lazdāns, 2006). The aim of this study is to compare productivity and cost of medium-sized and small-sized harvesters in pre-commercial thinning.

\section{MATERIAL AND METHODS}

The first part of the trials was done in summer, autumn and winter of 2013 in the central part of Latvia (in the vicinity of Skrīveri) in ten forest stand areas managed by the JSC "Latvian State Forests" (hereafter LSF). Similarly, data were collected in the summer of 2017 in the northern part of Latvia (in the vicinity of Ligatne) from trials in two private forest stands. Trial stands were selected by the average tree height of the dominant stand (ranges from 9 to $11 \mathrm{~m}$ ), stand density (the number of trees equals to or exceeds 2000 trees $^{-1} \mathrm{a}^{-1}$ ) and terrain suitable for mechanized logging. The study compares the data on productivity obtained in pre-commercial thinning using two medium-sized and two small-sized harvesters equipped with different types of felling heads. John Deere $1070 \mathrm{E}$ is a medium-sized harvester (mass: $15.5 \mathrm{t}$, engine power: $136 \mathrm{~kW}$ ), equipped with the $\mathrm{H} 754$ harvester head (weight: $820 \mathrm{~kg}$, felling diameter: $55 \mathrm{~cm}$, boom reach: $9 \mathrm{~m}$ ). John Deere 1070 D is a medium-sized harvester (mass: $14.1 \mathrm{t}$, engine power: $136 \mathrm{~kW}$ ), equipped with the Bracke C16.b harvester head (weight: $570 \mathrm{~kg}$, felling diameter: $26 \mathrm{~cm}$, boom reach: $9 \mathrm{~m}$ ). Rottne H8 is a small-sized harvester (mass: $10.2 \mathrm{t}$, engine power: $125 \mathrm{~kW}$ ), equipped with the EGS 406 harvester head (weight: $480 \mathrm{~kg}$, felling diameter: $33 \mathrm{~cm}$, boom reach: $7 \mathrm{~m}$ ). Vimek $404 \mathrm{SE}$ is a small-sized harvester (mass: $4.5 \mathrm{t}$, engine power: $50 \mathrm{~kW}$ ), equipped with the KETO Forst ECO harvester head (weight: $305 \mathrm{~kg}$, felling diameter: $30 \mathrm{~cm}$, boom reach: $4.6 \mathrm{~m}$ ). All the harvester heads are equipped with an accumulating device. Time study of harvesting was carried out manually by continuous time study method using hand-held data logger Allegro $\mathrm{CX}$. Total working time $\left(\mathrm{E}_{0}\right)$ represents the duration of the shift, but productive working time $\left(\mathrm{E}_{15}\right)$ is calculated by deducting the time spent on repairs and non-work activities. The average productivity figures, which are represented by the volume of timber produced per productive working hour in the relevant stem volume group, are plotted using the polynomial regression function represented by the equation 1:

$$
y=a+b * x+c * x^{2}
$$

Where $y$-productivity, $\mathrm{m}^{3} \mathrm{E}_{15} \mathrm{~h}^{-1} ; x$ - stem volume, $\mathrm{m}^{3} ; a, b, c$-regression coefficients. 
Prime cost calculation of harvesting was done according to the calculation models used in similar studies carried out previously (Ackerman et al., 2014; Kaleja et al., 2018). In the cost calculation it was assumed that harvester is employed 24 hours a day (each of the 2 operators works two 6-hour shifts). The average work productivity of each unit of the machinery was used for cost calculation. In order to determine the significance level of data, $\mathrm{T}$ - test and Wilcoxon signed-rank test were used.

\section{RESULTS AND DISCUSSION}

Small and medium-sized harvesters are more suitable for thinnings, where dimensions of felled trees are relatively small. Trial results show that the volume of most of the felled stems does not exceed $0.1 \mathrm{~m}^{3}$. When working with John Deere 1070 E harvester, 16.7 thousand trees were felled and $591 \mathrm{~m}^{3}$ of wood were prepared (the average tree height: $12.3 \mathrm{~m} ; \mathrm{d}_{1.3}: 8.8 \mathrm{~cm}$, stem volume: $0.04 \mathrm{~m}^{3}$ ). Within the scope of the study 17.9 thousand trees were felled using Rottne $\mathrm{H} 8$ harvester and $1089 \mathrm{~m}^{3}$ of wood were prepared (the average tree height: $11.4 \mathrm{~m}$; $\mathrm{d}_{1.3}: 10.2 \mathrm{~cm}$; stem volume: $0.07 \mathrm{~m}^{3}$ ). In areas, where John Deere $1070 \mathrm{D}$ harvester was used in thinnings, 13.4 thousand trees were felled, preparing $86 \mathrm{~m}^{3}$ of wood (the average tree height: $8.0 \mathrm{~m} ; \mathrm{d}_{1.3}: 4.3 \mathrm{~cm}$; stem volume: $0.01 \mathrm{~m}^{3}$ ). When using Vimek $404 \mathrm{SE}$ harvester, 3.9 thousand trees were felled, preparing $75 \mathrm{~m}^{3}$ of wood (the average tree height: $10.7 \mathrm{~m} ; \mathrm{d}_{1.3}: 7.2 \mathrm{~cm}$; stem volume: $0.02 \mathrm{~m}^{3}$ ). The number of trees felled with John Deere 1070 D harvester is relatively large, however the amount of prepared wood is small, which could be explained by the large share of undergrowth and small-dimension wood $\left(\mathrm{d}_{1.3}\right.$ smaller than $\left.3 \mathrm{~cm}\right)$ in the total amount of felled trees, which were not supposed to be felled according to the task of the study, except for cases, when it interferes with thinning. When analysing the average productivity rates of middle-class harvesters, on average 158 trees per productive hour were processed, preparing $5.6 \mathrm{~m}^{3}$ of wood (the average productive time $-83.5 \%$; time consumed for driving in and driving out $-4.6 \%$ of the total working time), using John Deere $1070 \mathrm{E}$ harvester. When using John Deere 1070 D harvester, on average 271 trees per productive hour were felled, preparing $1.7 \mathrm{~m}^{3}$ of wood (the average productive time $-75.2 \%$; time for driving in and driving out $-3.4 \%$ of the total working time). In similar studies that were carried out in Sweden and Finland in pre-commercial thinnings using middlesized harvesters the average productivity rates range from $3.8 \mathrm{~m}^{3} \mathrm{E}_{15} \mathrm{~h}^{-1}$ (the average stem volume: $0.09 \mathrm{~m}^{3}$; (Sirén, 2003)) to $9.5 \mathrm{~m}^{3} \mathrm{E}_{15} \mathrm{~h}^{-1}$ (the average stem volume: $0.05 \mathrm{~m}^{3}$; (Bergström, 2014)). Productivity rates shown by John Deere $1070 \mathrm{D}$ harvester are rather low and most likely the productivity has been influenced by the average stem volume of felled trees $\left(0.01 \mathrm{~m}^{3}\right)$, as well as by operator skills, when preparing small-dimension wood in forest stands (Kärhä, 2004). In trials that were carried out with Rottne H8 harvester on average 81 trees were processed per productive hour, preparing $5.0 \mathrm{~m}^{3}$ of wood (the average productive time $-83.7 \%$; time for driving in and driving out $-6.1 \%$ of the total working time). When using Vimek 404 ES harvester, on average 180 trees per productive working hour were processed, preparing $3.6 \mathrm{~m}^{3}$ of wood (the average productive time $-91.0 \%$; time for driving in and driving out $-3.0 \%$ of the total working time). Small-sized harvesters in pre-commercial thinnings have been studied in other countries as well and their productivity rates range from $5.6 \mathrm{~m}^{3} \mathrm{E}_{15} \mathrm{~h}^{-1}$ (the average stem volume $0.07 \mathrm{~m}^{3}$;(Kärhä, 2004)) to $8.8 \mathrm{~m}^{3} \mathrm{E}_{15} \mathrm{~h}^{-1}$ (the average stem volume $0.09 \mathrm{~m}^{3}$; (Sirén, 2003)). Latvian researchers have participated in a study, which involved trials conducted in Sweden with Vimek 404 T5 harvester with Keto Forest harvester head. The average productivity shown in these trials was $5.5 \mathrm{~m}^{3} \mathrm{E}_{15} \mathrm{~h}^{-1}$ 
(Lazdiňš, 2016), which indicate that, when improving skills of the operators, productivity increases (Ovaskainen, 2009). Comparing the average productivity rates between different harvesters, when felling trees, whose stem volume does not exceed $0.1 \mathrm{~m}^{3}$, John Deere $1070 \mathrm{E}$ harvester shows the best results in thinnings, followed by John Deere 1070 D, Vimek 404 SE and Rottne H8 harvester. Studies demonstrate that, when reaching certain stem dimensions, which correspond to the limit values of the use of harvesters, productivity ceases to increase or decreases (Nurminen, 2006). Similar results were obtained in these trials to (John Deere $1070 \mathrm{E}-0.33 \mathrm{~m}^{3}$; Rottne H8 $0.32 \mathrm{~m}^{3}$; John Deere $1070 \mathrm{D}-0.16 \mathrm{~m}^{3}$; Vimek $404 \mathrm{SE}-0.10 \mathrm{~m}^{3}$ ), productivity starts to decrease (Fig. 1).

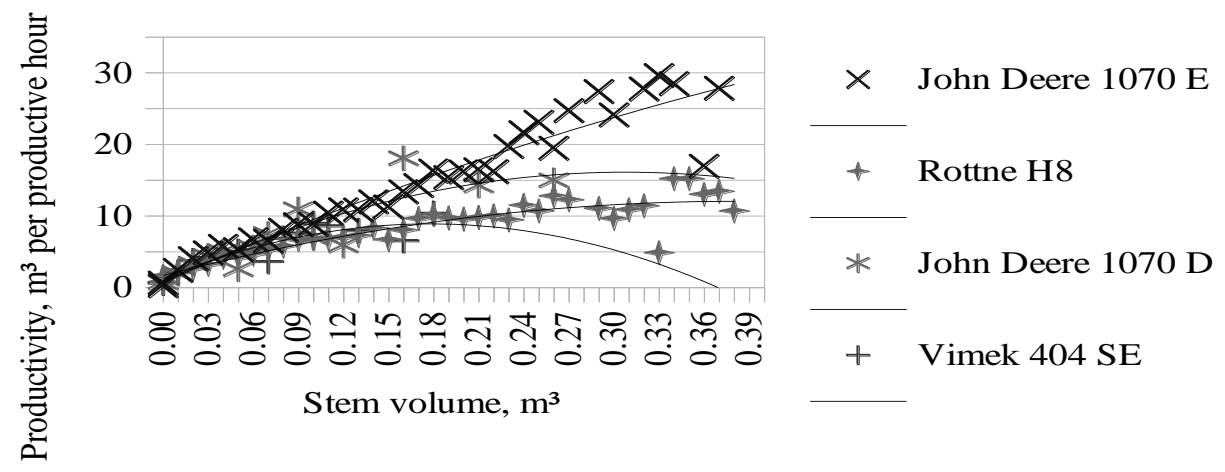

Figure 1. Comparison of average productivity of harvesters in different stem volume groups.

Significant differences were found, when comparing the average productivity of thinning carried out with John Deere $1070 \mathrm{E}$ harvester. The average productivity rates of this machine are significantly higher than by John Deere 1070 D $(p=0.008<0.05)$; Vimek 404 SE $(p=0.001<0.05)$ and Rottne H8 $(p=0.000003<0.05)$. In thinning average productivity of John Deere $1070 \mathrm{D}(\mathrm{p}=0.041<0.05)$ are significantly higher than productivity data obtained with Vimek 404 SE harvester. Regression analysis shows that the polynomial regression model explains 91.5 \% (John Deere 1070 E); 81.9 \% (Rottne H8); 80.4 \% (John Deere 1070 D) and $81.9 \%$ (Vimek 404 SE) of changes in productivity rates of harvesters in thinnings. Accordingly, the coefficients of linear regression equations of the average productivity rates of each harvester are shown in Table 1.

One of the main factors that influence the choice of a harvester is the costs of mechanized thinning. The total annual production costs of small-class harvesters are lower (119504 EUR for Vimek 404 SE and 131300 EUR for Rottne H8) than those of the middle-class harvesters (141 399 EUR for John Deere 1070 E and 142477 for John Deere 1070 D). For Vimek 404 SE harvester the costs are up to $16 \%$ lower than that of John Deere 1070 D harvester (the highest production costs), which are largely influenced by the low investment costs and operational costs (accordingly, $29 \%$ and $21 \%$ of the total costs). Personal costs for Vimek 404 SE harvester comprise the largest share of costs ( $45 \%$ of the total production costs). For the rest of harvesters personal costs comprise from $37 \%$ (John Deere 1070 E) to $41 \%$ (Rottne H8) of the total costs. Operational costs are to a large extent influenced by the necessity of maintenance and repairs and their share of the total costs range from 21\% (John Deere $1070 \mathrm{D}$ and 
Vimek 404 SE) to $25 \%$ (John Deere $1070 \mathrm{E}$ and Rottne H8). Also the profit of $5 \%$ is included in the total costs. The lowest costs per working hour were shown by Vimek 404 SE harvesters (39 EUR), followed by John Deere 1070 E and Rottne H8 harvesters (46 EUR) and John Deere 1070 D harvester (49 EUR). At the corresponding average productivity rates preparation of $1 \mathrm{~m}^{3}$ of wood with John Deere $1070 \mathrm{E}$ costs 8.3 EUR (the average productivity $5.6 \mathrm{~m}^{3} \mathrm{E}_{15^{-1}}$ ), with Rottne $\mathrm{H} 8-9.2 \mathrm{EUR}$ (the average productivity $-5 \mathrm{~m}^{3} \mathrm{E}_{15^{-1}}$ ), with Vimek $404 \mathrm{SE}-9.8 \mathrm{EUR}$ (the average productivity $3.9 \mathrm{~m}^{3} \mathrm{E}_{15^{-1}}$ ) and John Deere $1070 \mathrm{D}$ - $29.1 \mathrm{EUR}$ (the average productivity $1.7 \mathrm{~m}^{3} \mathrm{E}_{15^{-1}}$ ). Changes in wood preparation costs depending on stem value are given in Fig.2.

Table 1. Results of regression analysis of average productivity characteristics of harvesters used in thinning

\begin{tabular}{|c|c|c|c|c|c|}
\hline Harvester & Coefficient & $\begin{array}{l}\text { Estimate of } \\
\text { coefficient }\end{array}$ & $\begin{array}{c}\text { Standard error of } \\
\text { estimation }\end{array}$ & t-value & p-value \\
\hline \multirow[t]{3}{*}{ John Deere $1070 \mathrm{E}$} & $\mathrm{a}$ & 0.895868 & 1.071575 & 0.836028709 & 0.409338255 \\
\hline & $\mathrm{b}$ & 91.19156 & 14.47364 & 6.300525578 & $4.56023 \mathrm{E}-07$ \\
\hline & $\mathrm{c}$ & -49.6721 & 40.70066 & -1.220424181 & 0.231221528 \\
\hline \multirow[t]{3}{*}{ Rottne H8 } & $\mathrm{a}$ & 1.712063049 & 0.682744814 & 2.507617799 & 0.017094225 \\
\hline & $\mathrm{b}$ & 53.8443728 & 9.040072109 & 5.956188419 & $9.8169 \mathrm{E}-07$ \\
\hline & $\mathrm{c}$ & -69.75723927 & 24.73321021 & -2.820387595 & 0.007947637 \\
\hline \multirow[t]{3}{*}{ John Deere 1070 D } & $\mathrm{a}$ & 0.637783567 & 1.46680713 & 0.43481079 & 0.67210702 \\
\hline & $\mathrm{b}$ & 100.7931133 & 31.43759951 & 3.206132621 & 0.008362893 \\
\hline & c & -163.9584908 & 121.6288765 & -1.348022736 & 0.204755484 \\
\hline \multirow[t]{3}{*}{ Vimek 404 SE } & $\mathrm{a}$ & 1.285216303 & 0.785159549 & 1.636885528 & 0.127592473 \\
\hline & $\mathrm{b}$ & 85.88025259 & 20.8986593 & 4.109366603 & 0.001447908 \\
\hline & $\mathrm{c}$ & -242.0962293 & 114.6937837 & -2.11080515 & 0.056450717 \\
\hline
\end{tabular}

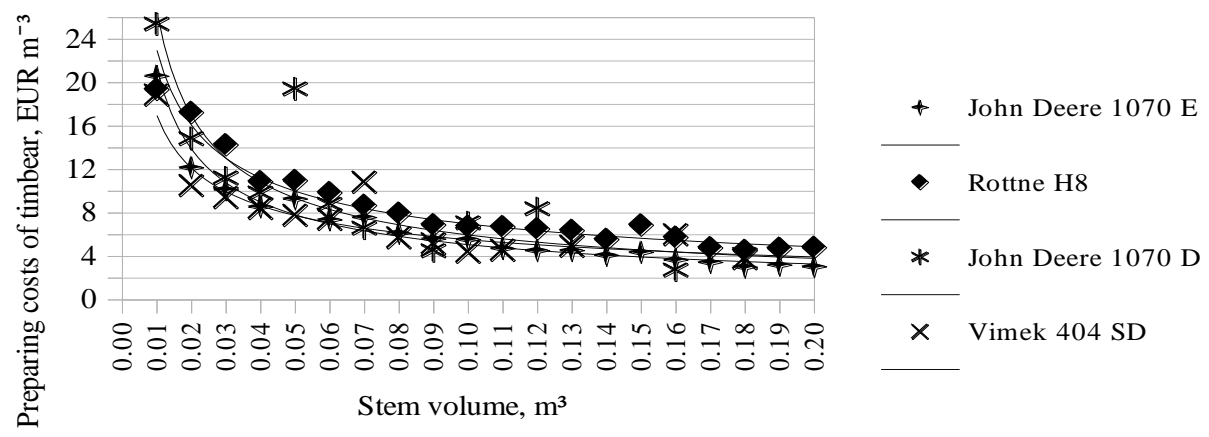

Figure 2. Wood preparation costs for different logging machines depending on stem volume

\section{CONCLUSIONS}


1. Comparing the harvesters used for thinning it was found that higher average productivity $\left(5.6 \mathrm{~m}^{3} \mathrm{E}_{15} \mathrm{~h}^{-1}\right.$; stem volume $0.03 \mathrm{~m}^{3}$ ) was achieved when using a medium-sized harvester John Deere 1070 E equipped with the H 754 harvester head. The average productivity shown by John Deere $1070 \mathrm{E}$ is significantly higher $(\mathrm{p}=0.008$ $<0.05$ ) than that of John Deere 1070 D equipped with the Bracke C16.b harvesting head. Comparing smallsized harvesters, higher productivity $\left(5.0 \mathrm{~m}^{3} \mathrm{E}_{15} \mathrm{~h}^{-1}\right.$; stem volume $\left.0.06 \mathrm{~m}^{3}\right)$ in thinning was achieved, when working with Rottne H8 equipped with the EGS 406 harvester head. Trials show that the average productivity is significantly influenced by operator skills.

2. The total annual costs of small-sized harvesters are lower than those of middle-class harvesters. The total costs of Vimek 404 SE harvester equipped with the KETO Forst ECO harvester head are up to $16 \%$ lower comparing with those of John Deere 1070 D harvester equipped with the Bracke C16.b harvester head (the highest production cost). The total costs are influenced by the relatively low investment and operational costs to a large extent.

3. According to the trials conducted, at the level of middle-sized harvesters wood preparation costs in thinnings are lower, when working with John Deere $1070 \mathrm{E}\left(8.3 \mathrm{EUR} \mathrm{m}^{-3}\right)$, but at the level of small-class harvesters when working with Rottne H8 $\left(9.2 \mathrm{EUR} \mathrm{m}^{-3}\right)$. This demonstrates that harvester productivity has a significant impact on wood preparation costs.

\section{REFERENCES}

1. Ackerman P., Belbo H., Eliasson L., de Jong A., Lazdins A., Lyons J. 2014. The COST model for calculation of forest operations costs. International Journal of Forest Engineering, 25(1), pp. $75-81$. https://doi.org/10.1080/14942119.2014.903711

2. Atjaunojamā energija un klimata pārmaiṇas (Renewable energy and climate change), 2014. Latvian Renewable Energy Federation, Available at https://www.laef.lv/files/LAEF buklets web 47b7ed63.pdf(In Latvian)

3. Bergström D., Di Fulvio F. 2014. Studies and Demonstration on the Use of a Novel Prototype Harvester Head in Early Fuel Wood Thinnings. Resarch report, Umeå. https://doi.org/10.1080/14942119.2014.945697

4. Central Statistical Bureau of Latvia, Available at https://www.csb.gov.lv/lv/statistika/statistikas-temas/videenergetika/energetika/meklet-tema/2404-energoresursu-paterins-latvija-2017-gada

5. Kalēja S., Lazdiņš A., Zimelis A., Spalva G. 2018. Model of Cost Calculation and Sensitivity Analysis of Forest Operations. Agronomy Research, Vol. 16(5), pp. 2068-2078.

6. Kärhä K., Rönkkö E., Gumse S. 2004. Productivity and Cutting Costs of Thinning Harvesters. International Journal of Forest Engineering, Vol. 15(2), pp. 43-56. https://doi.org/10.1080/14942119.2004.10702496

7. Latvijas ilgtspējīgas attīstības stratēgija līdz 2030. gadam (Latvian Sustainable Development Strategy 2030 ), 2010. Saeima of the Republic of Latvia, Rīga. Available at http://www.varam.gov.lv/lat/pol/ppd/?doc=13857 (In Latvian)

8. Lazdāns V., Epalts A., Lazdin̦š A. 2006. Enerǵētiskās koksnes resursu vērtējums, to sagatavošanas tehnologiijas un izmaksas, veicot kopšanas cirtes 20-40 gadus vecās mežaudzēs (Evaluation of energy wood resources, their processing technologies and costs in thinnings of 20-40 years old forest stands). Latvian State Forest Research Institute "Silava", Salaspils. (In Latvian) 
9. Lazdāns V., Lazdiņš A., Zimelis A., Nordén B., Iwarsson Wide, M., Von Hofsten H., Thor M. 2008. Biokurināmā ieguve sastāva kopšanas cirtēs, no grāvju un ceḷmalu apauguma, celmu pārstrādes, izvērtējot ekonomiskos, tehnoloǵiskos, vides un mežsaimnieciskos faktorus (Forest energy from small-dimension stands, "infrastructure objects" and stumps). SKOGFORSK, The Forest Research Institute of Sweden, Uppsala. (In Latvian)

10. Lazdāns, V., Lazdiņš, A., Zimelis, A. 2009. Biokurināmā sagatavošanas tehnoloǵija no mežizstrādes atliekām kailcirtes izstrādāšanā egḷu mežaudzēs ieguve sastāva kopšanas cirtēs, no grāvju un ceḷmalu apauguma, celmu pārstrādes, izvērtējot ekonomiskos, tehnoloğiskos, vides un mežsaimnieciskos faktorus (Technology of biofuel production from slash in clear-cuts un spruce stands). Mežzinātne, No. 19(52), pp.109-121. (In Latvian)

11. Lazdinš A., Kaleja S., Gruduls K., Bardulis A. 2013. Theoretical Evaluation of Wood for Bioenergy Resources in PreCommercial Thinning in Latvia.. Research for Rural Development, No. 2, pp. 42-48.

12. Lazdiňš A., Kaleja S., Zimelis A.2014. Factors Affecting Productivity and Cost of Solid Biofuel in Mechanized Forest Ditch Cleaning. Research for Rural Development, No. 2, pp. 90-96.

13. Lazdiņš A., Prindulis U., Kalēja S., Daugaviete M., Zimelis A. 2016. Productivity of Vimek 404 T5 Harvester and Vimek 610 Forwarder in Early Thinning. Agronomy Research, Vol. 14(2), pp.475-484.

14. Lazdiņš A., Zimelis A., Kalēja S. 2015. Biokurināmā sagatavošana jaunaudžu kopšanā, pirmajā krājas kopšanā un grāvju trašu apaugumā ar Moipu griezējgalvu (Preparation of biofuel in pre-commercial thinning, first thinning and ditch cleaning with Moipu harvesting head). Salaspils: LVMI Silava. (In Latvian)

15. Nurminen T., Korpunen H., Uusitalo J. 2006. Time Consumption Analysis of Harvesting System. Silva Fennica, Vol. 40(2), pp. 335-363. https://doi.org/10.14214/sf.346

16. Ovaskainen H. 2009. Timber harvester operators ' working technique in first thinning and the importance of cognitive abilities on work productivity. Faculty of Forest Sciences, University of Joensuu. https://doi.org/10.14214/df.79

17. Sirén M. 2003. Productivity and Costs of Thinning Harvesters and Harvester-Forwarders. International Journal of Forest Engineering, Vol. 14, pp. 39-48. https://doi.org/10.1080/14942119.2003.10702468

18. Wide I. M., Nordén B., Thor M., Lazdāns V., Lazdiṇš A. 2008. Biokurināmais no sīkkoku audzēm un apauguma meža infrastruktūras objektos (Biofuel from small stands and overgrowth in forest infrastructure). SKOGFORSK, The Forest Research Institute of Sweden, Uppsala (In Latvian) 